\title{
Vitamin K Measurement
}

National Cancer Institute

\section{Source}

National Cancer Institute. Vitamin K Measurement. NCI Thesaurus. Code C74907.

The determination of the amount of Vitamin $\mathrm{K}$ present in a sample. 